\title{
Article \\ Empirical Kinetic Modelling and Mechanisms of Quercetin Thermal Degradation in Aqueous Model Systems: Effect of pH and Addition of Antioxidants
}

\author{
Abdessamie Kellil ${ }^{1}$, Spyros Grigorakis ${ }^{1}$, Sofia Loupassaki ${ }^{1}$ and Dimitris P. Makris ${ }^{2, *}$ (i) \\ 1 Food Quality \& Chemistry of Natural Products, Mediterranean Agronomic Institute of Chania (M.A.I.Ch.), \\ International Centre for Advanced Mediterranean Agronomic Studies (CIHEAM), P.O. Box 85, \\ 73100 Chania, Greece; kellilabdessamie@gmail.com (A.K.); grigorakis@maich.gr (S.G.); sofia@maich.gr (S.L.) \\ 2 Department of Food Science \& Nutrition, School of Agricultural Sciences, University of Thessaly, \\ N. Temponera Street, 43100 Karditsa, Greece \\ * Correspondence: dimitrismakris@uth.gr; Tel.: +30-24410-64792
}

Citation: Kellil, A.; Grigorakis, S.; Loupassaki, S.; Makris, D.P. Empirical Kinetic Modelling and Mechanisms of Quercetin Thermal Degradation in Aqueous Model Systems: Effect of $\mathrm{pH}$ and Addition of Antioxidants. Appl. Sci. 2021, 11, 2579. https://doi.org/ 10.3390/app11062579

Academic Editor: Piotr Latocha

Received: 17 February 2021

Accepted: 11 March 2021

Published: 14 March 2021

Publisher's Note: MDPI stays neutral with regard to jurisdictional claims in published maps and institutional affiliations.

Copyright: ( $\odot 2021$ by the authors Licensee MDPI, Basel, Switzerland. This article is an open access article distributed under the terms and conditions of the Creative Commons Attribution (CC BY) license (https:// creativecommons.org/licenses/by/ $4.0 /)$.

\begin{abstract}
Quercetin (Qt) is a natural flavonoid of high biological significance, and it occurs in a wide variety of plant foods. Although its oxidation by various means has been extensively studied, its behavior with regard to thermal treatments remains a challenge. The study described herein aimed at investigating Qt thermal decomposition, by proposing an empirical sigmoidal model for tracing degradation kinetics. This model was employed to examine the effect of addition of antioxidants on Qt thermal degradation, including ascorbic acid, L-cysteine, and sulfite. Furthermore, degradation pathways were proposed by performing liquid chromatography-tandem mass spectrometry analyses. Upon addition of any antioxidant used, the sigmoidal course of Qt thermal degradation was pronounced, evidencing the validity of the empirical model used in the study of similar cases. The antioxidants retarded Qt degradation in a manner that appeared to depend on Qt/antioxidant molar ratio. No major differentiation in the degradation mechanism was observed in response to the addition of various antioxidants, and in all cases protocatechuic acid and phloroglucinol carboxylic acid were typical degradation products identified. Furthermore, in all cases tested the solutions resulted after thermal treatment possessed inferior antioxidant properties compared to the initial Qt solutions, and this demonstrated the detrimental effects of heating on Qt. The empirical model proposed could be of assistance in interpreting the degradation behavior of other polyphenols, but its validity merits further investigation.
\end{abstract}

Keywords: antioxidants; degradation kinetics; oxidation; quercetin

\section{Introduction}

Polyphenols are ubiquitous plant secondary metabolites, and they are undisputedly a highly significant field of interest in human nutrition. A growing body of research over the last two decades suggests that polyphenol intake through consumption of plant foods may play a vital role in maintaining a good health status, by regulating metabolism, battling chronic degenerative diseases, and controlling cell proliferation. To date, accumulated epidemiological evidence indicates that various polyphenols may exhibit strong antioxidant and anti-inflammatory properties, which could be implicated in the prevention of cardiovascular disease, neurodegenerative disorders, cancer, etc. [1].

Amongst several polyphenol classes, flavonols are probably one of the most prominent ones, because they are abundant at significant amounts in many commonly consumed fruit and vegetables, but also in foods of plant origin, such as fruit juices, tea and wine [2]. The major flavonol representative is quercetin, which occurs in plant tissues mainly as glycoside, although various types of processing may result in glycoside decomposition, releasing the aglycone [3]. Quercetin has powerful antioxidant properties, and its biological significance 
has been appraised by numerous investigations $[4,5]$. On the other hand, quercetin is a molecule susceptible to chemical and enzymic attacks, which may result in decomposition, skeleton rearrangement, and dimerization [6]. Such modifications can inevitably lead to alteration of the biological properties of quercetin, but this does not necessarily entail loss of biological activity. Decomposition or oxidation may end up in obtaining products of inferior antioxidant potency [7], but quercetin and other structurally related flavonoids were also shown to retain antioxidant activity, despite chemical or enzymic oxidation [8,9]. Quercetin oxidation may also result in generating compounds with enhanced biological activity [10]. Therefore, the changes in quercetin structure brought about through oxidative modification should be a subject of thorough appraisal.

The issue of food thermal processing on flavonols has been long before addressed, on the basis of findings which indicated that regular domestic practices (frying, boiling) could have an important impact on flavonol content and composition of certain plant tissues [11]. Latter studies confirmed that onion boiling may provoke notable decreases in flavonol glycosides and antioxidant activity, the extent of which was linked to glycoside structure [12]. More recent studies were in concurrence, highlighting the importance of domestic processing (frying, baking, steaming) on onion flavonol glycosides and its nutritional consequences [13]. Polyphenol thermal degradation has also been observed in black rice flour [14] and apple juice [15] thermal processing. However, other investigations suggested that the changes traced for flavonols in processed foods may depend on the mode of processing, yielding either increased or decreased flavonol content [16]. Indeed, it has been supported that heat treatments may contribute to increasing polyphenolic content in vegetables, as a result of thermal destruction of cell walls and sub cellular compartments during the cooking process, which would allow for polyphenol release [17].

Considering the above concepts, the current study aimed at assessing the effect of thermal treatment on quercetin degradation in model solutions. The phenomenon was approached by implementing a novel kinetic model, through which the effects of $\mathrm{pH}$ and addition of antioxidants were evaluated. The elucidation of quercetin degradation mechanism was carried out with liquid chromatography-tandem mass spectrometry (LCMS/MS), and putative consequences on the antioxidant activity were discussed on the ground of the results from representative in vitro assays. To the best of the authors' knowledge, such a kinetic approach is, for the first time, proposed for the study of polyphenol thermal degradation.

\section{Materials and Methods}

\subsection{Chemicals}

Potassium phosphate dibasic trihydrate ( $\geq 99 \%$ ), L-ascorbic acid, 2,2-diphenylpicrylhy drazyl (DPPH), sodium sulfite (>98\%), 2,4,6-tris(2-pyridyl)-s-triazine (TPTZ), quercetin dihydrate (>95\%), 3,4-dihydroxybenzoic acid (protocatechuic acid), 2,4,6-trihydroxybenzoic acid (phloroglucinol carboxylic acid), and citric acid were from Sigma-Aldrich (St. Louis, MO, USA). L-Cysteine was from BioChemica AppliChem (Darmstadt, Germany). Trolox ${ }^{\mathrm{TM}}$ was from Sigma-Aldrich (Steinheim, Germany). Iron(III) chloride hexahydrate was from Honeywell-Fluka (Harvey St, Muskegon, MI, USA). Quercetin stock solution with concentration of $20 \mathrm{mM}$ was prepared in acetone and stored at $-17^{\circ} \mathrm{C}$. Stock solution of L-ascorbic acid $(5 \mathrm{mM})$, L-cysteine $(5 \mathrm{mM})$, and sodium sulfite $(5 \mathrm{mM} \mathrm{mM})$ were prepared exactly before used in double-distilled water. Solvents used for liquid chromatography were of HPLC grade.

\subsection{Model Solutions and Thermal Treatment}

A volume of $50 \mathrm{~mL}$ of citrate-phosphate dibasic buffer, adjusted at $\mathrm{pH} 6.5,7.0$, and 7.5 , was placed in 100-mL dark glass vial and heated up at $90{ }^{\circ} \mathrm{C}$, by means of an oil bath, placed on a hotplate (VELP Scientifica, Bohemia, NY, USA). The solution was then set under stirring, at $400 \mathrm{rpm}$, and spiked with appropriate volume of quercetin stock solution, to give a final concentration of $100 \mu \mathrm{mol} \mathrm{L}^{-1}$. To test the effect of L-ascorbic acid, 
sodium sulfite, and L-cysteine, Qt solutions were also spiked with suitable volumes of stock solutions of these compounds, to provide the desired concentration.

\subsection{Degradation Kinetics}

To trace kinetics, sampling was accomplished at predetermined intervals by withdrawing $0.5 \mathrm{~mL}$ of model solution. This aliquot was then mixed with $0.5 \mathrm{~mL}$ methanol containing $2 \% \mathrm{HCl}$ and absorbance readings were obtained in a double-beam JASCO V-530 UV/Vis spectrophotometer (Tokyo, Japan). For monitoring quercetin degradation, absorbance was measured at wavelength corresponding to $\lambda_{\max }$ of the Band I of the flavonol skeleton [18]. The $\lambda_{\max }$ was determined by obtaining Qt UV-VIS spectrum within the range 200-600 nm, in a $50 \%$ aqueous methanol containing $1 \% \mathrm{HCl}$. A calibration curve was constructed by measuring the absorbance at $\lambda_{\max }$ and plotting it against concentration $\left(5-50 \mu \mathrm{mol} \mathrm{L}{ }^{-1}\right)$.

\subsection{Antioxidant Activity}

To assess the antioxidant activity of the model systems, two complementary tests were performed, the antiradical activity $\left(\mathrm{A}_{\mathrm{AR}}\right)$ and the ferric-reducing power $\left(\mathrm{P}_{\mathrm{R}}\right)$ [19]. Results for $A_{A R}$ and $P_{R}$ were expressed as mmol Trolox equivalents (TRE) and $\mu \mathrm{M}$ ascorbic acid equivalents (AAE), respectively.

\subsection{Liquid Chromatography-Tandem Mass Spectrometry (LC/MS/MS)}

The equipment used was a chromatograph TSQ Quantum Access LC/MS/MS, a surveyor pump (Thermo Scientific, Walltham, MA, USA), interfaced by XCalibur 2.1, TSQ 2.1 software. Chromatography was carried out on a Superspher RP-18 column, $125 \mathrm{~mm} \times 2 \mathrm{~mm}, 4 \mu \mathrm{m}$, at $40{ }^{\circ} \mathrm{C}$, with $10 \mu \mathrm{L}$ injection volume and a flow rate of $0.3 \mathrm{~mL}$ $\min ^{-1}$. Eluent (A) was $1 \%$ aqueous acetic acid and eluent (B) methanol containing $1 \%$ acetic acid. The elution program was a linear gradient, as follows: $0 \mathrm{~min}, 5 \% \mathrm{~B} ; 35 \mathrm{~min}$, $100 \%$ B. Mass spectra were acquired in negative ionization mode, after performing a full scan within 100-700 amu (scan time =1 s), using the following settings: auxiliary gas pressure, $15 \mathrm{mTorr}$; sheath gas pressure, $30 \mathrm{mTorr}$; collision pressure at $1.5 \mathrm{mTorr}$; capillary temperature, $300{ }^{\circ} \mathrm{C}$.

\subsection{Statistical Analysis}

Curve fitting for kinetic models, and all linear and non-linear regressions were performed with SigmaPlot ${ }^{\mathrm{TM}} 12.5$ (Systat Software Inc., San Jose, CA, USA). Distribution analysis was performed with JMP ${ }^{\text {TM }}$ Pro 13 (SAS, Cary, NC, USA). Determinations were carried out in triplicate and the values reported are average ( \pm standard deviation).

\section{Results and Discussion}

\subsection{The Effect of $p H$}

The thermal degradation of $\mathrm{Qt}$ at $90^{\circ} \mathrm{C}$ was first assessed as a function of $\mathrm{pH}$ near neutrality, that is, within the range 6.5-7.5. The evolution of the decrease of Qt concentration, $C\left(\mu \mathrm{mol} \mathrm{L}^{-1}\right)$, was plotted against time, $t(\mathrm{~s})$, and at all three $\mathrm{pH}$ values tested $(6.5,7.0$, and 7.5) it was observed that the curve obtained had a sigmoid trend (Figure 1). Therefore, a sigmoidal model was implemented, as follows:

$$
C_{t}=\frac{C_{0}}{1+e^{-\left(\frac{t-t_{1 / 2}}{b}\right)}}
$$

where $C_{0}$ and $C_{t}$ are the initial molar Qt concentration and the concentration at any time, $t$, respectively, $t_{1 / 2}$ is the half-life of the degradation reaction (s), and $-\frac{1}{b}$ the apparent first-order degradation rate, $k\left(\mathrm{~s}^{-1}\right)$. The examination was also carried out using first-order kinetics (Figure 2), as follows:

$$
\ln \left(\frac{C_{t}}{C_{0}}\right)=-k t
$$



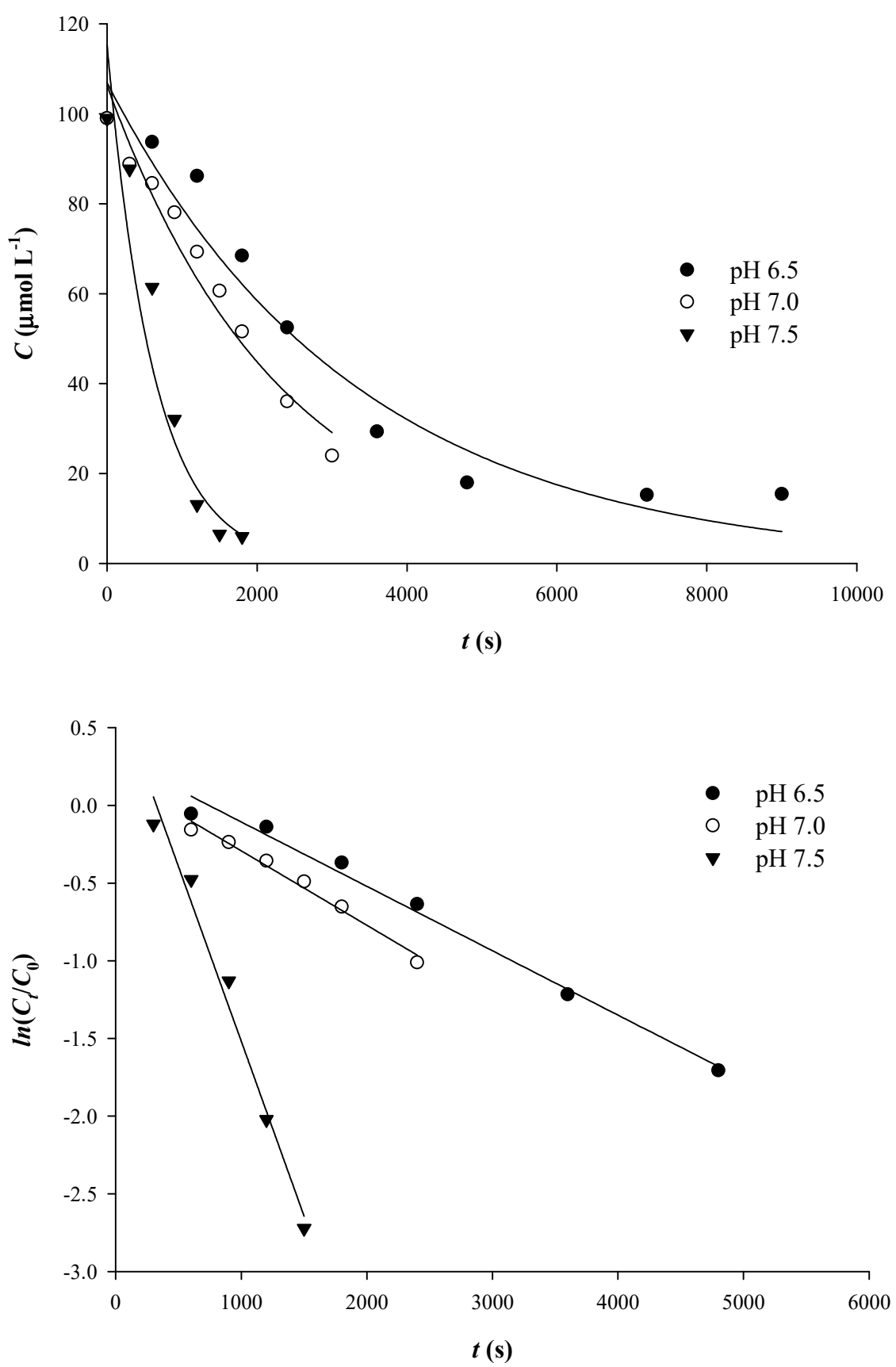

Figure 1. Kinetics of Qt thermal degradation $\left(100 \mu \mathrm{mol} \mathrm{L}{ }^{-1}\right)$ at $\mathrm{pH} 7.5$ and $90{ }^{\circ} \mathrm{C}$ (upper plot). Verification of the first-order kinetics are shown by a linear plot (lower plot).

The decline in absorbance is virtually stabilized after some time, which actually signified the end of the reaction within the time limits initially set. These points do not contribute in tracing kinetic curves, and they were, therefore, excluded from the linear representation in Figure 1.

As can be seen in Table 1, the implementation of the sigmoidal model exhibited higher $\mathrm{R}^{2}$, which indicated a better fitting to the experimental data compared to first-order model. However, for both sigmoidal and first-order models, the statistical significance was higher than $95 \%(p<0.05)$. 


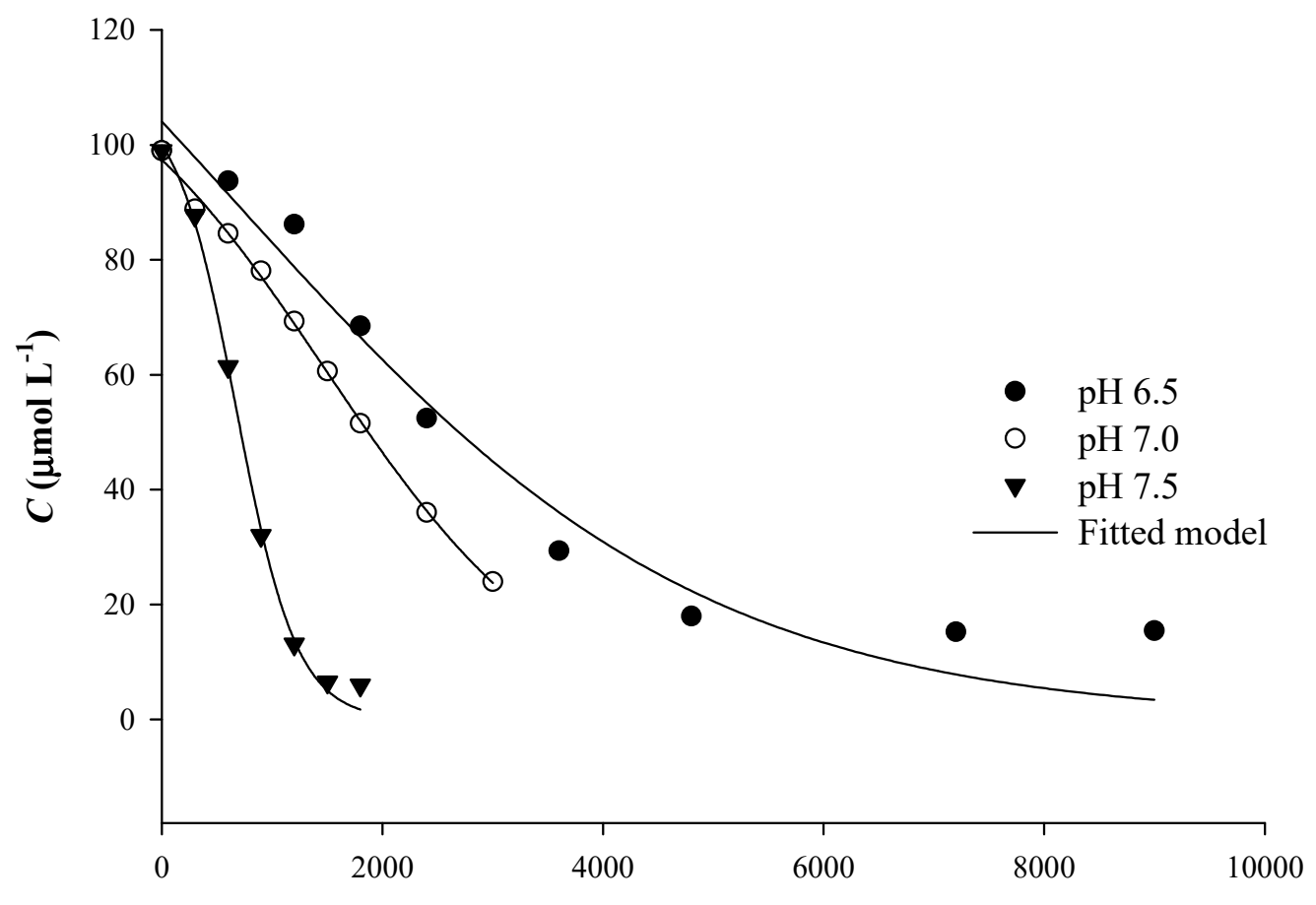

t (s)

Figure 2. Adjustment of the sigmoidal model on the kinetic data obtained for Qt thermal degradation at various $\mathrm{pH}$.

Table 1. Kinetic data generated after implementing first-order and sigmoidal kinetic models.

\begin{tabular}{ccccccc}
\hline & \multicolumn{3}{c}{ First-Order Model } & \multicolumn{3}{c}{ Sigmoidal Model } \\
\cline { 2 - 7 } $\mathbf{p H}$ & $\begin{array}{c}\boldsymbol{k}\left(\mathbf{s}^{-\mathbf{1}}\right) \\
\left(\times \mathbf{1 0}^{-\mathbf{3}}\right)\end{array}$ & $\boldsymbol{t}_{\frac{1}{2}}(\mathbf{s})$ & $\mathbf{R}^{\mathbf{2}}$ & $\begin{array}{c}\boldsymbol{k}\left(\mathbf{s}^{-\mathbf{1}}\right) \\
\left(\times \mathbf{1 0}^{-3}\right)\end{array}$ & $\boldsymbol{t}_{\frac{1}{2}}(\mathbf{s})$ & $\mathbf{R}^{\mathbf{2}}$ \\
\hline 6.5 & 0.30 & 2310 & 0.94 & 0.76 & 2189 & 0.99 \\
7.0 & 0.40 & 1733 & 0.97 & 0.92 & 1470 & 0.99 \\
7.5 & 1.60 & 433 & 0.93 & 3.65 & 673 & 1.00 \\
\hline
\end{tabular}

Determination of degradation rate constants, $k$, and degradation half-lives, $t_{1 / 2}$, revealed important discrepancies between models (Table 1$)$. In particular, $k$ determined that the sigmoidal model were 2.3 to 2.5 higher than those determined with the first-order model. However, for $\mathrm{pH} 7.5, t_{1 / 2}$ determined with the sigmoidal model was 1.55 -times higher than that determined with the first-order model. This finding pointed to an underestimation of the degradation rate constant, when the first-order model was used, but also to a different relationship between $k$ and $t_{1 / 2}$ in the sigmoidal model, as implied by Equation (1). At this point, the issue that arises is the reason for which the sigmoidal model, which rather traces Qt degradation more accurately, delivers higher $k$. The monitoring of Qt degradation is carried out by recording the decrease in $\lambda_{\max }(370 \mathrm{~nm})$. Yet, decrease of absorbance at 370 nm occurs not when Qt starts to break down into simpler phenolics, but as soon as Qt is converted into the initial oxidation product, which is its quinone (Figure 3) [20].

Should this be the case, then initially, decrease in $\lambda_{\max }$ might be slower. This is because Qt quinone exhibits a $\lambda_{\max }$ at around 425-430 $\mathrm{nm}$ [21] and, thus, it may possess notable absorbance at $370 \mathrm{~nm}$, which would affect monitoring of Qt disappearance. First-order kinetics fails to incorporate this stage, and the points included in tracing Qt degradation are those corresponding to rapid Qt disappearance, which takes place during quinone decomposition. Cleavage of the Qt quinone skeleton would lead to decreases at $370 \mathrm{~nm}$, yielding degradation products (simpler phenolics) that possess practically no absorbance at this region of the spectrum [22]. This is most probably the rationale behind the differences 
observed when kinetic parameters were determined with the sigmoidal model instead of the first-order model.<smiles>O=C(O)c1ccc(O)c(O)c1</smiles>

(1)<smiles>O=C(O)c1c(O)cc(O)cc1O</smiles>

(2)<smiles>O=C1C=CC(C(=O)C(=O)c2c(O)cc(O)cc2O)=CC1=O</smiles>

(4)<smiles>O=C1C=CC(c2oc3cc(O)cc(O)c3c(=O)c2O)=CC1=O</smiles>

(3)<smiles>O=C(O)C(=O)C1=CC(=O)C(=O)C=C1</smiles>

(6)<smiles>O=C1C=CC(c2oc3cc(O)cc(O)c3c(=O)c2OS(=O)(=O)O)=CC1=O</smiles><smiles>O=c1c(OS(=O)(=O)O)c(-c2ccc(O)c(O)c2)oc2cc(O)cc(O)c12</smiles>

Figure 3. Structures of Qt degradation/oxidation/reaction products tentatively identified in the model solutions tested. Assignments: (1) Protocatechuic acid $(m / z=151)$; (2) phloroglucinol carboxylic acid $(m / z=169)$; (3) Qt quinone ( $m / z=299)$; (4), 2,3,4,-chalcan-trione $o$-quinone; (5) 3,4-dione-2-oxo-phenylacetic acid ( $\mathrm{m} / z=179)$; (6) Qt 3-sulfate $(\mathrm{m} / z=381)$; (7) Qt 3-sulfate quinone $(m / z=379)$.

The determination of $k$ with either model demonstrated an approximate 5-fold increase from $\mathrm{pH} 6.5$ to 7.5 , illustrating the effect of $\mathrm{pH}$. Although information on thermal degradation kinetics of quercetin at $95{ }^{\circ} \mathrm{C}$ was previously provided to some extent [23], no data regarding the effect of $\mathrm{pH}$ at similar temperatures have been reported. Early examinations demonstrated the dependence of quercetin oxidative degradation on $\mathrm{pH}$ within the range $4-7$, suggesting a logarithmic increase in first-order kinetics constant as a function of $\mathrm{pH}$, at $50{ }^{\circ} \mathrm{C}$ [24]. In the same line, more recent studies showed an increase in first-order decomposition of quercetin as $\mathrm{pH}$ increased from 6.0 to 7.5 [25]. It was proposed that quercetin deprotonation at alkaline $\mathrm{pH}$ accelerates its oxidation, affecting the $\mathrm{C}$-ring and the $o$-diphenol structure of the B-ring, and leading to the formation of a benzofuranone derivative $[26,27]$.

The LC-MS/MS analysis of a Qt solution after treatment at $90{ }^{\circ} \mathrm{C}$ for $50 \mathrm{~min}$ (Figure 4) enabled the tentative identification of typical degradation products, including protocatechuic acid (PCA) and phloroglucinol carboxylic acid (PGCA) (Table 2; Figure 3). 


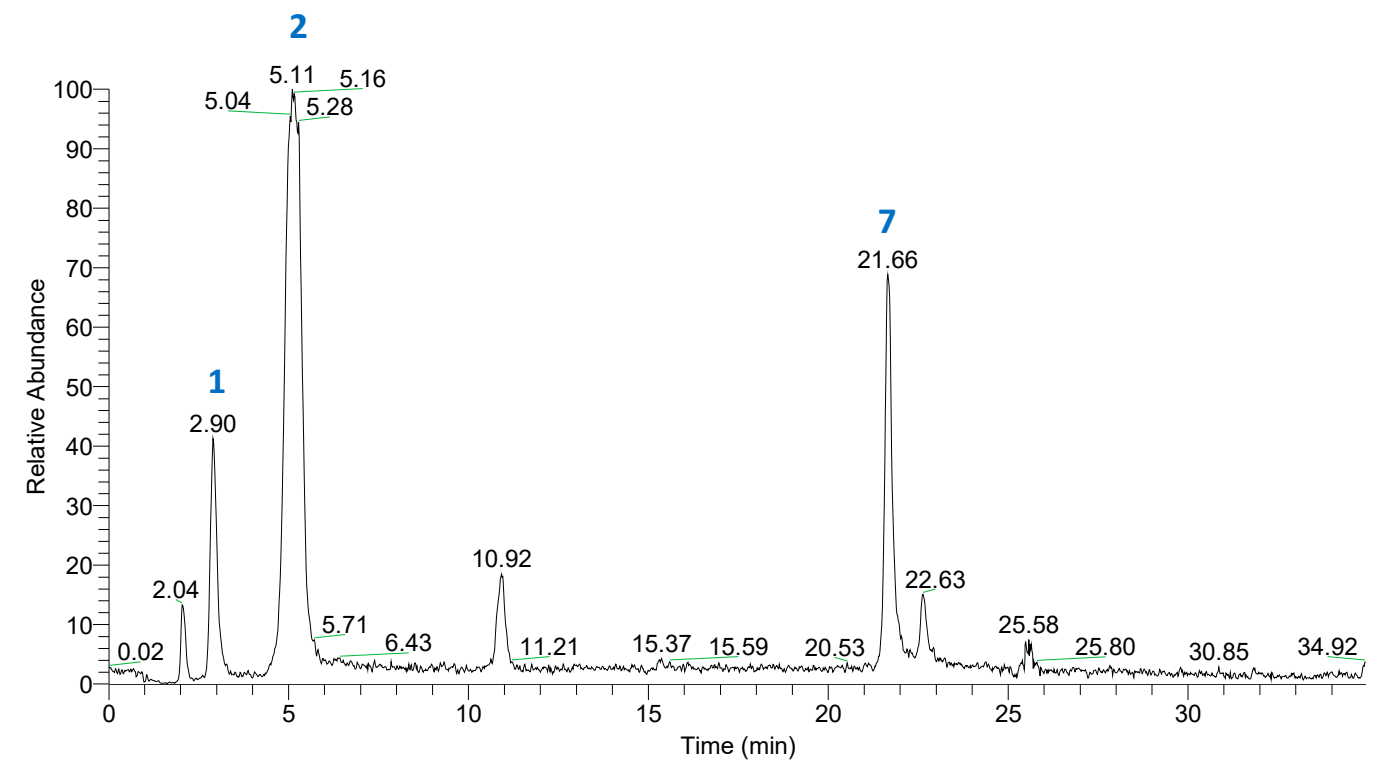

Figure 4. Total ion chromatogram (TIC) of a Qt solution $(100 \mu \mathrm{mol} \mathrm{L}-1)$, treated at $90^{\circ} \mathrm{C}$, for $50 \mathrm{~min}$, at $\mathrm{pH}$ 7.5. For peak assignment, see Table 2.

Table 2. Mass spectral data of the major Qt degradation products, detected in Qt solutions after treatment for 50 min, at $90{ }^{\circ} \mathrm{C}$.

\begin{tabular}{|c|c|c|c|c|c|c|c|c|c|}
\hline Peak \# & $\begin{array}{c}\mathrm{Rt} \\
(\mathrm{min})\end{array}$ & $\begin{array}{l}\text { Molecular Ion } \\
\quad(\mathrm{m} / \mathrm{z})\end{array}$ & $\begin{array}{l}\text { Other } \\
\text { Fragments } \\
(\mathrm{m} / \mathrm{z})\end{array}$ & Tentative Identity & Formula & $Q t^{a}$ & $Q t+A_{s A}{ }^{b}$ & $\underset{\mathrm{CySH}^{\mathrm{c}}}{\mathrm{Qt}+}$ & $Q t+$ Sulfite $^{d}$ \\
\hline 1 & 2.90 & 169 & $151\left(-\mathrm{H}_{2} \mathrm{O}\right)$ & $\begin{array}{c}\text { Phloroglucinol carboxylic } \\
\text { acid } \\
(2,4,6 \text {-trihydroxybenzoic } \\
\text { acid) }\end{array}$ & $\mathrm{C}_{7} \mathrm{H}_{5} \mathrm{O}_{5}$ & + & + & + & + \\
\hline 2 & 5.16 & 153 & $109\left(-\mathrm{CO}_{2}\right)$ & $\begin{array}{c}\text { Protocatechuic acid } \\
\text { (2,4-dihydroxybenzoic acid) }\end{array}$ & $\mathrm{C}_{7} \mathrm{H}_{5} \mathrm{O}_{4}$ & + & + & + & + \\
\hline 3 & 12.10 & 179 & 119 & $\begin{array}{l}\text { 3,4-dione-2-oxo-phenylacetic } \\
\text { acid }\end{array}$ & $\mathrm{C}_{8} \mathrm{H}_{3} \mathrm{O}_{5}$ & - & + & - & - \\
\hline 4 & 12.41 & 381 & - & Quercetin 3-sulfate & $\mathrm{C}_{15} \mathrm{H}_{13} \mathrm{O}_{7} \mathrm{~S}$ & - & - & - & + \\
\hline 5 & 14.22 & 379 & - & Quercetin 3-sulfate quinone & $\mathrm{C}_{15} \mathrm{H}_{11} \mathrm{O}_{7} \mathrm{~S}$ & - & - & - & + \\
\hline 6 & 20.27 & 301 & - & Quercetin & $\mathrm{C}_{15} \mathrm{H}_{10} \mathrm{O}_{7}$ & - & + & + & + \\
\hline 7 & 21.66 & 299 & - & Quercetin quinone & $\mathrm{C}_{15} \mathrm{H}_{8} \mathrm{O}_{7}$ & + & + & + & + \\
\hline
\end{tabular}

${ }^{\text {a }}$ Treatment of $100 \mu \mathrm{mol} \mathrm{L}{ }^{-1} \mathrm{Qt}^{b}$ Treatment of $100 \mu \mathrm{mol} \mathrm{L}^{-1} \mathrm{Qt}+200 \mu \mathrm{mol} \mathrm{L}^{-1}$ AsA; ${ }^{\mathrm{c}}$ Treatment of $100 \mu \mathrm{mol} \mathrm{L}{ }^{-1} \mathrm{Qt}+200 \mu \mathrm{mol} \mathrm{L}{ }^{-1}$ $\mathrm{CySH} ;{ }^{\mathrm{d}}$ Treatment of $100 \mu \mathrm{mol} \mathrm{L}{ }^{-1} \mathrm{Qt}+200 \mu \mathrm{mol} \mathrm{L}^{-1}$ sulfite.

Identification of both PCA and PGCA was based on mass spectral data previously reported [28]. Qt quinone was also detected, which confirmed its formation as an intermediate in $\mathrm{Qt}$ degradation. The typical oxidation product 2-(hydroxybenzoyl)-2-hydroxybenzof uran-3(2H)-one (benzofuranone), which may arise as a result of Qt oxidation by various means [28], was not detected. This fact might be attributed to the relatively high temperature of the treatment, which most probably triggered benzofuranone thermal decomposition. On the other hand, alternative oxidation pathways might have taken place as previously proposed [18,29], resulting in PCA and PGCA formation. It should be noted that Qt oxidation in the absence of $\mathrm{H}_{2} \mathrm{O}_{2}$ did not yield PCA and PGCA [30,31]. Therefore, the degradation pathway(s) involved would be likely to include formation of $\mathrm{H}_{2} \mathrm{O}_{2}$ too, as intermediate. This could arise through reaction of $\mathrm{O}_{2}$ with $2 \mathrm{H}$ atoms offered by $\mathrm{Qt}$, hence the formation of Qt quinone. Such a reaction would be facilitated at the mildly alkaline $\mathrm{pH}$ used (7.5). Then $\mathrm{H}_{2} \mathrm{O}_{2}$ nucleophilic attack at the $\mathrm{C} 2$ position would lead to cross ring cyclic peroxylation, resulting an intermediate depside. Decomposition of this depside would eventually yield PCA and PGCA [31]. Such a reaction would also be feasible through radical formation, as previously suggested [29]. 


\subsection{The Effect of AsA Addition}

To test the effect of AsA, increasing AsA amounts varying from 10 to $200 \mu \mathrm{mol} \mathrm{L}^{-1}$ were added into Qt solutions, to provide a Qt/AsA molar ratio range from 10 to 0.5 . In this case, the sigmoidal course of degradation was more evident as AsA concentration increased (Figure 5). Although AsA at levels of 10 and $25 \mu \mathrm{mol} \mathrm{L}^{-1}$ resulted in lower $k$, an increasing trend observed for $k$, from 10 and up to $100 \mu \mathrm{mol} \mathrm{L}^{-1}$ AsA (Table 3). However, the differences in $k$ compared to control treatment (no AsA addition) were about $14 \%$, at most. On the other hand, $t_{1 / 2}$ displayed a consistent increasing tendency within the whole range of AsA concentrations tested. This outcome suggested that the effect of AsA on $k$ was dependent on $\mathrm{Qt} / \mathrm{AsA}$ molar ratio, but a rise in AsA concentration up to a $\mathrm{Qt} / \mathrm{AsA}$ molar ration of 0.5 provided a proportional Qt stability, as implied by the increased $t_{1 / 2}$.

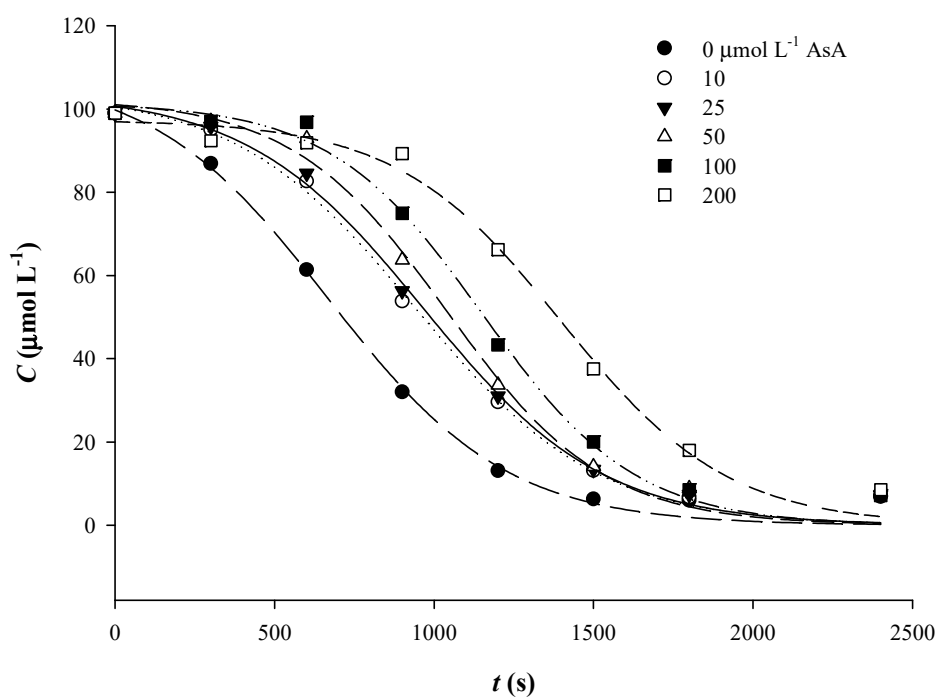

Figure 5. Implementation of the sigmoidal kinetic model to trace Qt thermal degradation in the presence of various concentrations of AsA.

Table 3. The effect of antioxidants on Qt degradation kinetics using the sigmoidal model.

\begin{tabular}{|c|c|c|c|}
\hline \multirow[t]{2}{*}{ Antioxidant Added $\left(\mu \mathrm{mol} \mathrm{L} \mathrm{L}^{-1}\right)$} & \multicolumn{3}{|c|}{ Kinetic Constants * } \\
\hline & $k\left(\mathrm{~s}^{-1}\right)\left(\times 10^{-3}\right)$ & $t_{\frac{1}{2}}(\mathrm{~s})$ & $\mathbf{R}^{2}$ \\
\hline No Addition & 3.65 & 673 & 1.00 \\
\hline \multicolumn{4}{|l|}{ AsA } \\
\hline 10 & 3.51 & 942 & 0.99 \\
\hline 25 & 3.58 & 969 & 0.99 \\
\hline 50 & 4.09 & 1042 & 0.99 \\
\hline 100 & 4.18 & 1151 & 0.99 \\
\hline 200 & 3.86 & 1402 & 0.99 \\
\hline \multicolumn{4}{|l|}{$\mathrm{CySH}$} \\
\hline 10 & 3.36 & 709 & 1.00 \\
\hline 25 & 2.84 & 749 & 0.99 \\
\hline 50 & 2.37 & 880 & 0.99 \\
\hline 100 & 2.11 & 875 & 1.00 \\
\hline 200 & 2.10 & 855 & 0.99 \\
\hline \multicolumn{4}{|l|}{$\mathrm{Na}_{2} \mathrm{SO}_{3}$} \\
\hline 10 & 3.09 & 901 & 0.99 \\
\hline 25 & 3.51 & 885 & 0.99 \\
\hline 50 & 3.42 & 865 & 0.99 \\
\hline 100 & 3.21 & 910 & 0.99 \\
\hline 200 & 2.78 & 980 & 0.99 \\
\hline
\end{tabular}

* Significance of model fitting was at a level higher than $99.9 \%(p<0.0001)$. 
Such a phenomenon could be attributed to a stabilizing effect on Qt quinone, or, if Qt radical formation has preceded, donation of a $\mathrm{H}$ atom to convert $\mathrm{Qt}$ radical back to Qt. The latter would prevent $\mathrm{O}_{2}$-mediated oxidation of $\mathrm{Qt}$, which would further decompose into simpler phenolics [29]. The fact that Qt was oxidized first could be supported by its lower oxidation potential, compared to AsA [32,33].

Therefore, it would be likely that, in a mixture of AsA and Qt, the latter is preferably oxidized, giving rise to Qt radicals and/or Qt quinone. Then, AsA might scavenge $\mathrm{O}_{2}$ (and/or $\mathrm{H}_{2} \mathrm{O}_{2}$ ), delaying to some extent further Qt oxidation and decomposition. This is likely the reason for determining increasing $t_{1 / 2}$ upon addition of increasing AsA concentration.

Upon depletion of AsA, Qt would react with $\mathrm{O}_{2}\left(\right.$ or $\left.\mathrm{H}_{2} \mathrm{O}_{2}\right)$ generating eventually PCA and PGCA. To verify whether the presence of AsA could alter the mechanism of Qt decomposition, the mixture of Qt treated in the presence of $200 \mu \mathrm{mol} \mathrm{L}^{-1}$ AsA for $50 \mathrm{~min}$, at $90^{\circ} \mathrm{C}$, was analyzed by LC-MS/MS. Once again, as in the case of Qt alone, the major compounds detected were PCA and PGCA, but also another one with $m / z=179$. The latter was tentatively assigned to 3,4-dione-2-oxo-phenylacetic acid (Figure 3), and it could derive from decomposition of 2,3,4-chalcan-trione $o$-quinone, as previously proposed [31]. In such a case, formation of Qt quinone should precede and, therefore, it could be supported that, in the presence of AsA, Qt quinone formation and subsequent decomposition could be a plausible predominant pathway.

\subsection{The Effect of CySH Addition}

As in the case of AsA addition, the sigmoidal course of Qt decomposition was also pronounced by the addition of increasing amounts of $\mathrm{CySH}$ (Figure 6), compared to control, although less so compared to AsA. The addition of increasing amounts of CySH resulted in a consistently decreasing tendency in $k$, and when CySH was added at a level of 200 $\mu \mathrm{mol} \mathrm{L}{ }^{-1}$, Qt displayed the least $k$, which was by almost $43 \%$ lower compared to control (no CySH addition). On the other hand, $t_{1 / 2}$ increased up to $50 \mu \mathrm{mol} \mathrm{L}^{-1} \mathrm{CySH}$, but then it exhibited a rather stabilizing trend (Table 3). Based on the hypothesis set out for AsA, it would appear that $\mathrm{CySH}$ stabilized Qt quinone by preventing quinone reaction with oxygen, or by acting as radical scavenger, up to $50 \mu \mathrm{mol} \mathrm{L}{ }^{-1}$; additional increase in $\mathrm{CySH}$ had no or little effect. Stabilizing effect of $\mathrm{CySH}$ against thermally-induced, coppercatalyzed oxidative Qt degradation has been previously reported to occur at 1:1 molar ratio [34]. The authors attributed this protective action to the ability of CySH to react with oxygen, giving stable products, such as L-cystine, L-cysteine sulphinic acid, and L-cysteine sulphonic acid. On the other hand, under different conditions, CySH might accelerate Qt degradation through the involvement of cysteinyl radicals [18]. However, given the stabilizing effect observed, the latter case would be rather unlikely.

The chromatographic profile of a Qt mixture with $200 \mu \mathrm{mol} \mathrm{L}^{-1} \mathrm{CySH}$, after $50 \mathrm{~min}$ of treatment at $90^{\circ} \mathrm{C}$, did not show any difference compared to that of Qt alone, and the major products detected were PCA, PGCA, and Qt quinone (Table 2). Unlike previous examinations [18,34], the appearance of peaks that would manifest Qt reaction with $\mathrm{CySH}$ was not evidenced. Such a finding would strongly point to a non-radical degradation mechanism, as also supported for Qt/AsA mixtures.

\subsection{The Effect of Sulfite Addition}

Similarly to what was observed by addition of either AsA or $\mathrm{CySH}$, the sigmoidal course of Qt degradation was more evident by the addition of sodium sulfite (Figure 7). At a concentration of $10 \mu \mathrm{mol} \mathrm{L}-1$, sulfite provoked a decrease in $k$ by almost $15 \%$ compared to control (no sulfite addition), but at $25 \mu \mathrm{mol} \mathrm{L}^{-1}$ an increase was recorded (Table 3). Thereafter, $k$ followed a constant decline, as in the case of CySH. Likewise, although $t_{1 / 2}$ decreased up to $50 \mu \mathrm{mol} \mathrm{L}^{-1}$, from 100 to $200 \mu \mathrm{mol} \mathrm{L}^{-1}$ an increase was seen. This outcome indicated that sulfite showed a consistent stabilizing effect from $50 \mu \mathrm{mol} \mathrm{L}^{-1}$ onwards. 


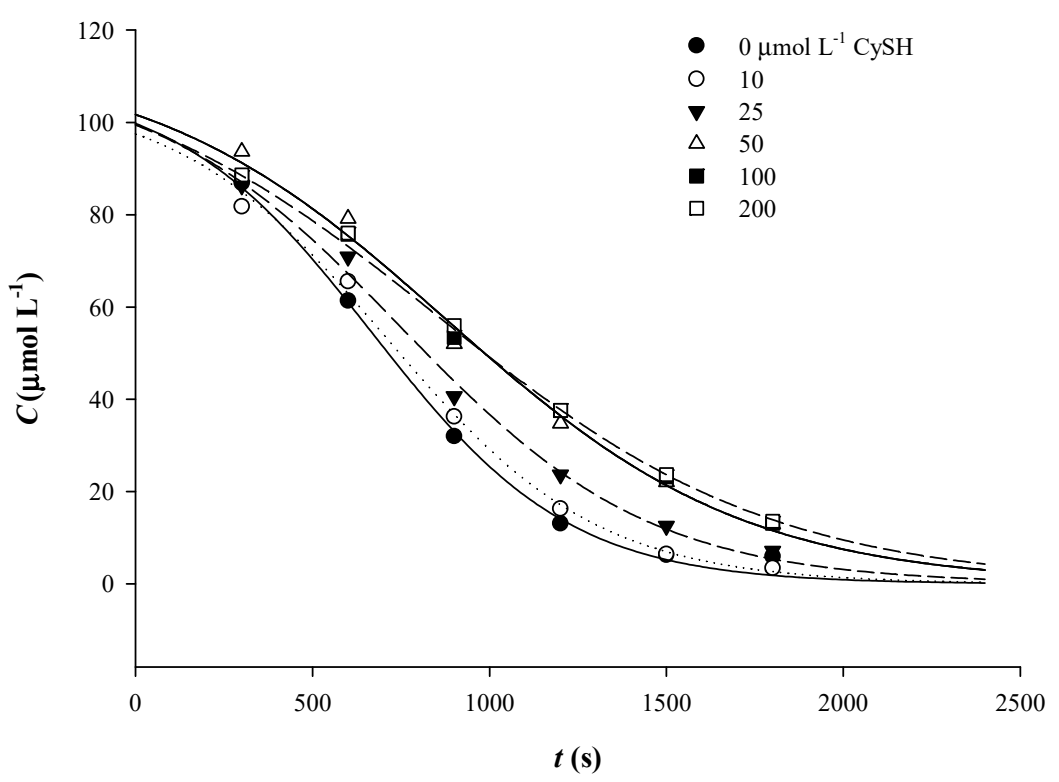

Figure 6. Implementation of the sigmoidal kinetic model to trace Qt thermal degradation in the presence of various concentrations of $\mathrm{CySH}$.

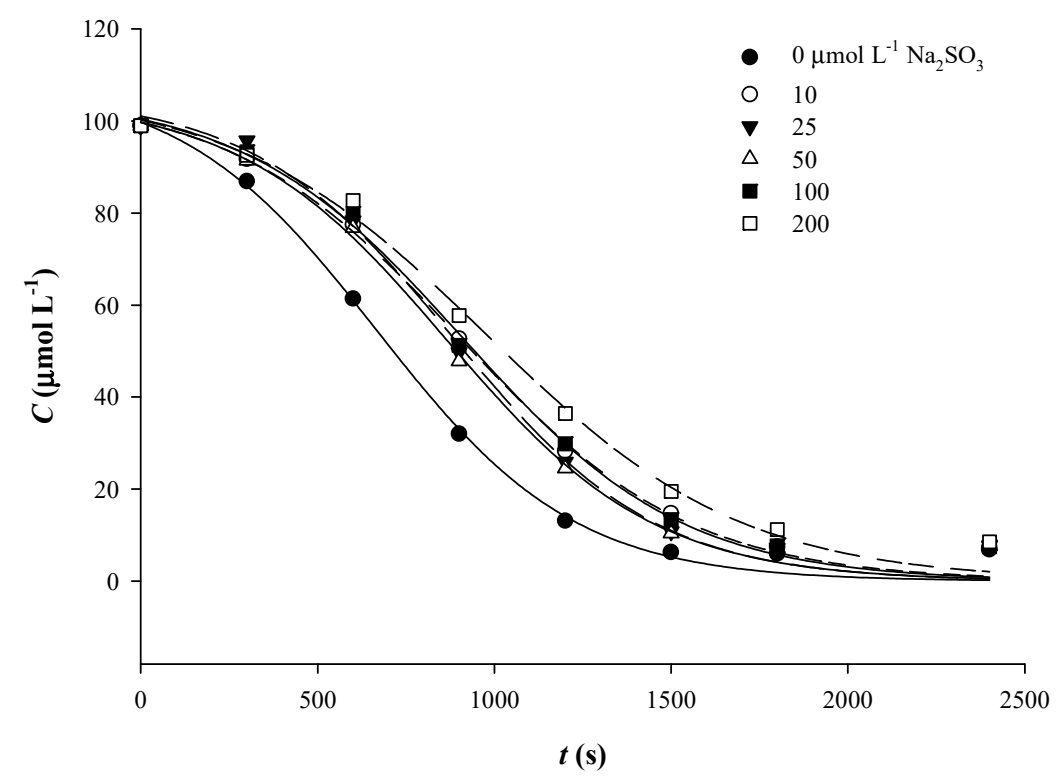

Figure 7. Implementation of the sigmoidal kinetic model to trace Qt thermal degradation in the presence of various concentrations of sulfite.

Sulfite may act as oxygen scavenger and reducing agent [35]. Therefore, the protective action it could exert would be through preventing reaction of Qt (or Qt quinone) with oxygen, or reduction of the Qt quinone back to Qt. Sulfur dioxide $\left(\mathrm{SO}_{2}\right)$ has been proven to prevent Qt electrochemical oxidation [36], and the authors claimed that the antioxidant protection seen was a result of quinone reduction or semiquinone radical reduction. Judging by the degradation products generated, it was also concluded that Qt oxidative degradation follows the same pathway, irrespective of the presence of $\mathrm{SO}_{2}$. To test this hypothesis, as well as to shed more light onto the effect of sulfite on Qt oxidative degradation, a Qt solution treated for $50 \mathrm{~min}$, at $90^{\circ} \mathrm{C}$, in the presence of $200 \mu \mathrm{mol} \mathrm{L}^{-1}$ sodium sulfite, was subjected to LC-MS/MS analysis. Apart from the typical degradation products PCA, PGCA and Qt quinone, two other peaks with $m / z=381$ and 379 were also detected (Table 3). These compounds were encountered neither in Qt solutions, nor in Qt solutions treated with AsA and CySH. The peak with $m / z=381$ might correspond to Qt 3-sulfate, as 
previously proposed [37,38], while the peak with $m / z=379$ could be its quinone (Figure 3). This finding raised evidence for plausible reaction(s) between $Q t$ and sulfite.

\subsection{Impact on Antioxidant Activity}

To test whether Qt decomposition could impact its antioxidant properties to a significant extent, a Qt solution of $100 \mu \mathrm{mol} \mathrm{L}^{-1}$ was assayed before and after treatment at $\mathrm{pH}$ 7.5 and $90{ }^{\circ} \mathrm{C}$, for $50 \mathrm{~min}$. As can be seen in Figure 8, both $\mathrm{A}_{\mathrm{AR}}$ and $\mathrm{P}_{\mathrm{R}}$ were significantly reduced after treatment $(p<0.05)$. This outcome clearly pointed to a detrimental effect of $\mathrm{Qt}$ thermal break down on its antioxidant potency. The examination of solutions with $200 \mu \mathrm{mol} \mathrm{L}{ }^{-1}$ of either AsA, CySH and sulfite showed that $\mathrm{A}_{\mathrm{AR}}$ may be less affected, although the reduction was still significant compared to non-treated Qt solution. Regarding $P_{R}$, the reduction was significant irrespective of the antioxidant added.
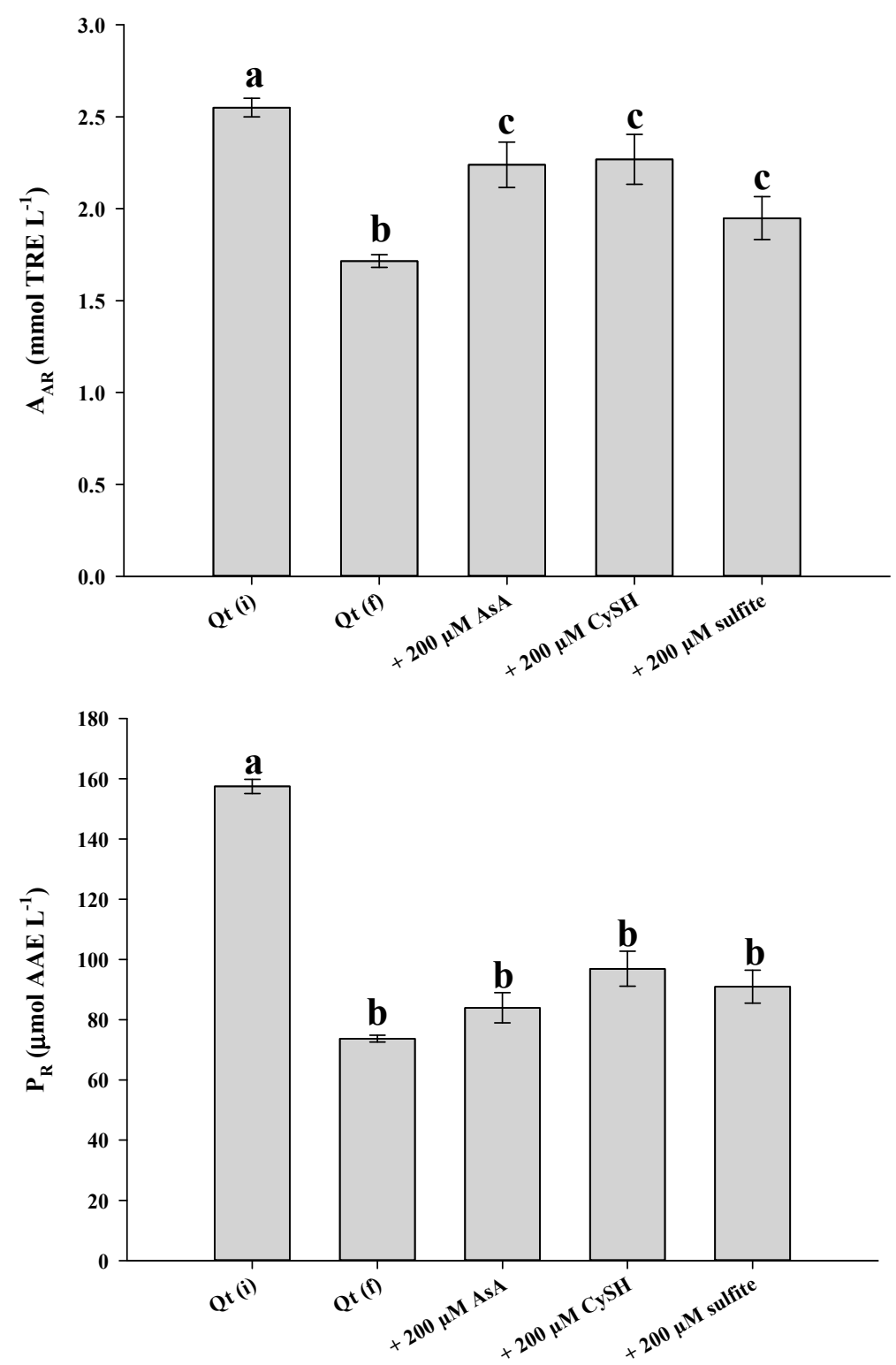

Figure 8. Antiradical activity (upper plot) and ferric-reducing power (lower plot) of a Qt solution $\left(100 \mu \mathrm{mol} \mathrm{L}^{-1}\right)$, at $\mathrm{pH} 7.5$, prior to thermal treatment $(\mathrm{Qt}(\mathrm{i}))$, after 50 min at $90^{\circ} \mathrm{C}(\mathrm{Qt}(\mathrm{f}))$ and after $50 \mathrm{~min}$ at $90^{\circ} \mathrm{C}$ in the presence of $200 \mu \mathrm{mol} \mathrm{L}{ }^{-1} \mathrm{AsA}, \mathrm{CySH}$ and sulfite. Bars designated with different letters indicate statistically different value $(p<0.05)$. 
Qt is considered a powerful antioxidant, due to unique structural features, which are not encountered in other flavonoids, such as the combination of the o-diphenol in B-ring, the C2-C3 double bond, the 4-oxo group and the 5-hydroxyl group [39]. Once the skeleton is cleaved, these features are abrogated and thus it would be reasonable to anticipate reduced antioxidant activity. Furthermore, the two major degradation products, PCA and PGCA, have been proven to be of considerably lower efficiency [22]. AsA, CySH, and sulfite may also degrade and/or oxidize to some extent and apparently could not compensate for the antioxidant activity lost.

\section{Conclusions}

The thermal degradation of Qt in an aqueous model system, at $\mathrm{pH} 7.5$, was shown to obey a sigmoidal curve, and on this ground a novel empirical kinetic model was proposed, to investigate the decomposition behavior of Qt. This sigmoidal trend was even more evident when Qt solutions were treated in the presence of compounds that express antioxidant effect, including AsA, $\mathrm{CySH}$, and sulfite. In all cases it was found that addition of antioxidants may delay Qt thermal degradation, but this depended on the molar ratio $\mathrm{Qt} /$ antioxidant. Some reaction products between $\mathrm{Qt}$ and sulfite tentatively identified may also play a role in this regard. However, the typical degradation products detected were PCA and PGCA, irrespective of the antioxidant added. In any case, the solution resulted after thermal treatment possessed inferior antioxidant properties compared to the initial Qt solution, and this demonstrated the detrimental effects of heating on Qt. The kinetic model proposed should be considered strictly as empirical, and it may be of assistance in interpreting the degradation behavior of other polyphenols. Thus, testing of a wider range of structures could reveal its validity in assessing various factors $(\mathrm{pH}$, antioxidants) in polyphenol thermal degradation, but also its limitations, which are yet to be defined.

Author Contributions: Conceptualization: D.P.M.; methodology: D.P.M., S.G.; validation: A.K., S.G.; formal analysis: A.K., S.G., S.L.; data curation: D.P.M., S.G., A.K.; writing一original draft preparation: D.P.M.; visualization: D.P.M., S.G., A.K.; supervision: D.P.M. All authors have read and agreed to the published version of the manuscript.

Funding: This research received no external funding.

Institutional Review Board Statement: Not applicable.

Informed Consent Statement: Not applicable.

Data Availability Statement: Not applicable.

Conflicts of Interest: The authors declare no conflict of interest.

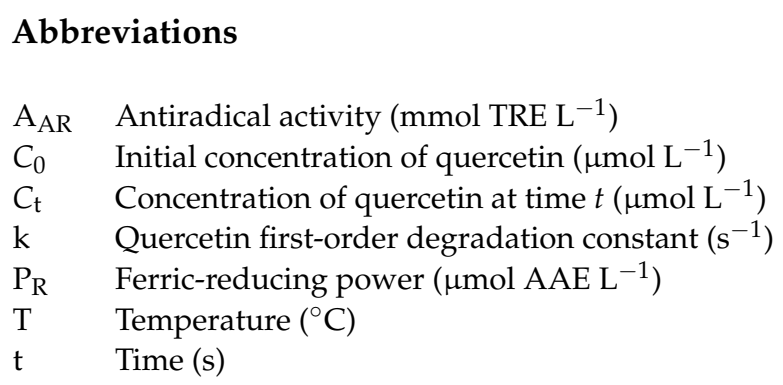

\section{References}

1. Cory, H.; Passarelli, S.; Szeto, J.; Tamez, M.; Mattei, J. The role of polyphenols in human health and food systems: A mini-review. Front. Nutr. 2018, 5, 87. [CrossRef]

2. Kamiloglu, S.; Tomas, M.; Capanoglu, E. Dietary Flavonols and O-Glycosides. In Handbook of Dietary Phytochemicals; Springer: Singapore, 2019; pp. 1-40.

3. Deng, S.; West, B.J.; Jensen, C.J. Thermal degradation of flavonol glycosides in noni leaves during roasting. Adv. J. Food Sci. Technol. 2011, 3, 155-159. 
4. Calani, L.; Dall'Asta, M.; Bruni, R.; Rio, D.D. Flavonoid occurrence, bioavailability, metabolism, and protective effects in humans: Focus on Flavan-3-ols and Flavonols. In Recent Advances in Polyphenol Research; John Wiley \& Sons, Ltd.: Chichester, UK, 2014; pp. 239-279.

5. Wang, W.; Sun, C.; Mao, L.; Ma, P.; Liu, F.; Yang, J.; Gao, Y. The biological activities, chemical stability, metabolism and delivery systems of quercetin: A review. Trends Food Sci. Technol. 2016, 56, 21-38. [CrossRef]

6. Zhou, A.; Sadik, O.A. Comparative analysis of quercetin oxidation by electrochemical, enzymatic, autoxidation, and free radical generation techniques: A mechanistic study. J. Agric. Food Chem. 2008, 56, 12081-12091. [CrossRef] [PubMed]

7. Buchner, N.; Krumbein, A.; Rohn, S.; Kroh, L.W. Effect of thermal processing on the flavonols rutin and quercetin. Rapid Commun. Mass Spectrom. 2006, 20, 3229-3235. [CrossRef]

8. Atala, E.; Fuentes, J.; Wehrhahn, M.J.; Speisky, H. Quercetin and related flavonoids conserve their antioxidant properties despite undergoing chemical or enzymatic oxidation. Food Chem. 2017, 234, 479-485. [CrossRef] [PubMed]

9. Chaaban, H.; Ioannou, I.; Chebil, L.; Slimane, M.; Gérardin, C.; Paris, C.; Charbonnel, C.; Chekir, L.; Ghoul, M. Effect of heat processing on thermal stability and antioxidant activity of six flavonoids. J. Food Proc. Preserv. 2017, 41, e13203. [CrossRef]

10. Fuentes, J.; Atala, E.; Pastene, E.; Carrasco-Pozo, C.; Speisky, H.N. Quercetin oxidation paradoxically enhances its antioxidant and cytoprotective properties. J. Agric. Food Chem. 2017, 65, 11002-11010. [CrossRef]

11. Price, K.R.; Bacon, J.R.; Rhodes, M.J. Effect of storage and domestic processing on the content and composition of flavonol glucosides in onion (Allium cepa). J. Agric. Food Chem. 1997, 45, 938-942. [CrossRef]

12. Makris, D.P.; Rossiter, J.T. Domestic processing of onion bulbs (Allium cepa) and asparagus spears (Asparagus officinalis): Effect on flavonol content and antioxidant status. J. Agric. Food Chem. 2001, 49, 3216-3222. [CrossRef] [PubMed]

13. Harris, S.; Brunton, N.; Tiwari, U.; Cummins, E. Human exposure modelling of quercetin in onions (Allium cepa L.) following thermal processing. Food Chem. 2015, 187, 135-139. [CrossRef] [PubMed]

14. Bolea, C.; Turturică, M.; Stănciuc, N.; Vizireanu, C. Thermal degradation kinetics of bioactive compounds from black rice flour (Oryza sativa L.) extracts. J. Cereal Sci. 2016, 71, 160-166. [CrossRef]

15. De Paepe, D.; Valkenborg, D.; Coudijzer, K.; Noten, B.; Servaes, K.; De Loose, M.; Voorspoels, S.; Diels, L.; Van Droogenbroeck, B. Thermal degradation of cloudy apple juice phenolic constituents. Food Chem. 2014, 162, 176-185. [CrossRef]

16. Lombard, K.; Peffley, E.; Geoffriau, E.; Thompson, L.; Herring, A. Quercetin in onion (Allium cepa L.) after heat-treatment simulating home preparation. J. Food Compos. Anal. 2005, 18, 571-581. [CrossRef]

17. Juániz, I.; Ludwig, I.A.; Huarte, E.; Pereira-Caro, G.; Moreno-Rojas, J.M.; Cid, C.; De Peña, M.-P. Influence of heat treatment on antioxidant capacity and (poly) phenolic compounds of selected vegetables. Food Chem. 2016, 197, 466-473. [CrossRef]

18. Photiades, A.; Grigorakis, S.; Makris, D.P. Kinetics and modeling of L-cysteine effect on the Cu (II)-induced oxidation of quercetin. Chem. Eng. Commun. 2020, 207, 139-152. [CrossRef]

19. Arnous, A.; Makris, D.P.; Kefalas, P. Correlation of pigment and flavanol content with antioxidant properties in selected aged regional wines from Greece. J. Food Compos. Anal. 2002, 15, 655-665. [CrossRef]

20. Hajji, H.E.; Nkhili, E.; Tomao, V.; Dangles, O. Interactions of quercetin with iron and copper ions: Complexation and autoxidation. Free Radic. Res. 2006, 40, 303-320. [CrossRef]

21. Dangles, O.; Fargeix, G.; Dufour, C. One-electron oxidation of quercetin and quercetin derivatives in protic and non protic media. J. Chem. Soc. Perkin Trans. 2 1999, 1, 1387-1396. [CrossRef]

22. Makris, D.P.; Rossiter, J.T. Comparison of quercetin and a non-orthohydroxy flavonol as antioxidants by competing in vitro oxidation reactions. J. Agric. Food Chem. 2001, 49, 3370-3377. [CrossRef]

23. Makris, D.P.; Rossiter, J.T. Heat-induced, metal-catalyzed oxidative degradation of quercetin and rutin (quercetin 3-Orhamnosylglucoside) in aqueous model systems. J. Agric. Food Chem. 2000, 48, 3830-3838. [CrossRef] [PubMed]

24. Mocek, M.; Richardson, P.J. Kinetics and mechanism of quercetin oxidation. J. Inst. Brew. 1972, 78, 459-465. [CrossRef]

25. Wang, J.; Zhao, X.-H. Degradation kinetics of fisetin and quercetin in solutions as effected by $\mathrm{pH}$, temperature and coexisted proteins. J. Serb. Chem. Soc. 2016, 81, 243-253. [CrossRef]

26. Jurasekova, Z.; Torreggiani, A.; Tamba, M.; Sanchez-Cortes, S.; Garcia-Ramos, J. Raman and surface-enhanced Raman scattering (SERS) investigation of the quercetin interaction with metals: Evidence of structural changing processes in aqueous solution and on metal nanoparticles. J. Mol. Struct. 2009, 918, 129-137. [CrossRef]

27. Jurasekova, Z.; Domingo, C.; García-Ramos, J.V.; Sánchez-Cortés, S. Effect of pH on the chemical modification of quercetin and structurally related flavonoids characterized by optical (UV-visible and Raman) spectroscopy. Phys. Chem. Chem. Phys. 2014, 16, 12802-12811. [CrossRef] [PubMed]

28. Zenkevich, I.; Pushkareva, T. Systematization of the results of the chromatography-mass spectrometry identification of the products of quercetin oxidation by atmospheric oxygen in aqueous solutions. J. Anal. Chem. 2017, 72, 1061-1075. [CrossRef]

29. Osman, A.; Makris, D.P.; Kefalas, P. Investigation on biocatalytic properties of a peroxidase-active homogenate from onion solid wastes: An insight into quercetin oxidation mechanism. Process Biochem. 2008, 43, 861-867. [CrossRef]

30. Makris, D.P.; Rossiter, J.T. Hydroxyl free radical-mediated oxidative degradation of quercetin and morin: A preliminary investigation. J. Food Compos. Anal. 2002, 15, 103-113. [CrossRef]

31. Barnes, J.S.; Schug, K.A. Oxidative degradation of quercetin with hydrogen peroxide using continuous-flow kinetic electrosprayion trap-time-of-flight mass spectrometry. J. Agric. Food Chem. 2014, 62, 4322-4331. [CrossRef] 
32. Abou Samra, M.; Chedea, V.S.; Economou, A.; Calokerinos, A.; Kefalas, P. Antioxidant/prooxidant properties of model phenolic compounds: Part I. Studies on equimolar mixtures by chemiluminescence and cyclic voltammetry. Food Chem. 2011, 125, 622-629. [CrossRef]

33. Choueiri, L.; Chedea, V.S.; Calokerinos, A.; Kefalas, P. Antioxidant/pro-oxidant properties of model phenolic compounds. Part II: Studies on mixtures of polyphenols at different molar ratios by chemiluminescence and LC-MS. Food Chem. 2012, 133, 1039-1044. [CrossRef]

34. Makris, D.P.; Rossiter, J.T. Effect of natural antioxidants on heat-induced, copper (II)-catalysed, oxidative degradation of quercetin and rutin (quercetin 3-O-rutinoside) in aqueous model systems. J. Sci. Food Agric. 2002, 82, 1147-1153. [CrossRef]

35. Barberá, J.J.; Metzger, A.; Wolf, M. Sulfites, thiosulfates, and dithionites. In Ullmann's Encyclopedia of Industrial Chemistry; Wiley-VCH Verlag GmbH \& Co: Weinheim, Germany, 2000.

36. Makhotkina, O.; Kilmartin, P.A. Electrochemical oxidation of wine polyphenols in the presence of sulfur dioxide. J. Agric. Food Chem. 2013, 61, 5573-5581. [CrossRef] [PubMed]

37. Ouyang, Z.; Cao, X.; Wei, Y.; Zhao, M.; Duan, J.-A. Pharmacokinetic study of rutin and quercetin in rats after oral administration of total flavones of mulberry leaf extract. Rev. Bras. Farm. 2013, 23, 776-782. [CrossRef]

38. Kleinenkuhnen, N.; Büchel, F.; Gerlich, S.C.; Kopriva, S.; Metzger, S. A novel method for identification and quantification of sulfated flavonoids in plants by neutral loss scan mass spectrometry. Front. Plant Sci. 2019, 10, 885. [CrossRef]

39. Amorati, R.; Baschieri, A.; Cowden, A.; Valgimigli, L. The antioxidant activity of quercetin in water solution. Biomimetics 2017, 2, 9. [CrossRef] [PubMed] 